\title{
Advances in analytical techniques for polychlorinated dibenzo-p-dioxins, polychlorinated dibenzofurans and dioxin-like PCBs
}

Received: 6 February 2006 / Revised: 4 April 2006 / Accepted: 10 April 2006 / Published online: 23 June 2006

C) Springer-Verlag 2006

\begin{abstract}
Analytical techniques for the determination of polychorinated dibenzo- $p$-dioxins (PCDD), polychlorinated dibenzofurans (PCDF) and dioxin-like PCBs (DLPCB) are reviewed. The focus of the review is on recent advances in methodology and analytical procedures. The paper also reviews toxicology, the development of toxic equivalent factors (TEF) and the determination of toxic equivalent quantity (TEQ) values. Sources, occurrence and temporal trends of PCDD/PCDF are summarized to provide examples of levels and concentration ranges for the methods and techniques reviewed.
\end{abstract}

Keywords Review - Polychlorinated dibenzo-p-dioxins · PCDD - Polychlorinated dibenzofurans - PCDF - Dioxinlike PCBs - DLPCB - Extraction - Sample preparation Analysis · Mass spectrometry · Toxicity · Environmental levels

\section{Introduction}

In this review, we describe the current state-of-the-art for the determination of the chlorinated dibenzo- $p$-dioxins (dioxins), chlorinated dibenzofurans (furans), and dioxinlike polychlorinated biphenyls (DLPCBs, or coplanar PCBs). Only a brief summary of the historical development of methods for these compounds is given here; all of the

E. J. Reiner $(\bowtie) \cdot$ R. E. Clement

Ontario Ministry of the Environment,

Toronto, ON, Canada, M9P 3V6

e-mail: eric.reiner@ene.gov.on.ca

Tel.: +1-416-2355743

Fax: +1-416-2355744

\section{A. B. Okey}

Department of Pharmacology, University of Toronto,

Toronto, ON, Canada, M5S 1A8

C. H. Marvin

Environment Canada,

Burlington, ON, Canada, L7R 4A6 most important earlier work has been summarized in previous reviews [1-4].

The characteristics of modern methods for dioxin/furan/ DLPCB determination are derived from several factors related to their chemical, physical and toxicological properties. The exceptionally high toxicity of $2,3,7,8$ tetrachlorodibenzo- $p$-dioxin $(2,3,7,8$-TCDD) meant from the outset that very low detection limits (DLs) were required; consideration of their hydrophobic nature and concern over chronic rather than acute toxicity effects meant that bioaccumulation was of increased concern, which pushed the need for even lower DLs. An understanding of the environmental levels, transport and fate of these compounds is important if we wish to understand the significance of these compounds as well as the low detection limits and broad range of detection required; therefore, a section on levels, transport and fate of these compounds is included in this review. A variety of different analytical methods and techniques have been developed to increase sensitivity and selectivity and to reduce analysis times. To fully understand the analytical methods developed and their application, the references cited in Table 5 should be examined. Table 5 also illustrates the wide range of sample types and concentration ranges of dioxins and DLPCBs detected in the global environment, which explains why so many variations on the basic analytical methodology exist.

Another factor in method development and application was the large amount of litigation that occurred because of the detection of these compounds in humans as well as the environment. Methods of analysis were required to generate data that could withstand scrutiny in a court of law, which led to the necessity of using methods based on isotope dilution-HRMS techniques. In addition, the rapid growth in high-quality standards and reference materials contributed to substantial improvements in the accuracy and precision of modern methods.

The development of analytical methods was also influenced by the need for regulators to be able to evaluate the combined toxicity of a number of compounds that have similar toxic properties to $2,3,7,8-\mathrm{TCDD}$, but widely 
varying potencies. This development is so important to the development of analytical methods that we have included a section below on toxicology and TEFs. The bottom line for dioxin methods was that definitive separation of the 2,3,7,8-substituted dioxins/furans and DLPCBs from a large number of other congeners with almost identical physical and chemical properties, as well as numerous other potentially interfering compounds, was essential.

Brief background on dioxin determination

Chlorinated dibenzo- $p$-dioxins (dioxins) have been of concern for decades because of their toxic properties, as described below. A structurally similar series of compounds, the chlorinated dibenzofurans (furans), have similar chemical properties and toxic effects, and are generally determined as a group with the dioxins. In recent years there has been a growing trend to include a specific subgroup of the polychlorinated biphenyls (PCBs): the socalled dioxin-like PCBs (DLPCBs). This has been added to methods along with the dioxins and furans. Figure 1 shows the structures of 2,3,7,8-TCDD, 2,3,7,8-TCDF and PCB126. The carbon numbering system is marked next to each carbon to indicate substitution positions. Dioxin and furan congeners substituted in the $2,3,7$ or 8 position are toxic, while PCBs substituted in the $3,3^{\prime}, 4,4^{\prime}, 5$ or $5^{\prime}$ position and no or only one 2- or 2'-substitution are considered to be dioxin-like and to exhibit dioxin toxicity (see Table 1).

Originally, attention was focused on the most toxic member of these substances, 2,3,7,8-TCDD. Gas chromatographic columns were soon developed that could separate 2,3,7,8-TCDD from the other 21 TCDD isomers in sample extracts [5], and other columns that could fortuitously separate the groups of congeners from each other by degree of chlorination (i.e., all tetrachlorinated dioxins/furans were eluted, followed by all of the pentachlorinated dioxins/furans, followed by the hexachlorinated, then the heptachlorinated, then the octachlorinated [6]. Many early publications reported a so-called congener group determination, where the total concentrations of all of the isomers from each group containing the same number of substituent chlorines were quantified and summed. Under this approach, 11 concentrations would be reported: total tetrachlorinated dioxins $\left(\mathrm{T}_{4} \mathrm{CDDs}\right)$, total pentachlorinated dioxins $\left(\mathrm{P}_{5} \mathrm{CDDs}\right)$, total hexachlorinated dioxins $\left(\mathrm{H}_{6} \mathrm{CDDs}\right)$, total heptachlorinated dioxins $\left(\mathrm{H}_{7} \mathrm{CDDs}\right)$, the octachlorinated dioxin (OCDD), the same dibenzofuran groups $\left(\mathrm{T}_{4} \mathrm{CDFs}, \mathrm{P}_{5} \mathrm{CDFs}, \mathrm{H}_{6} \mathrm{CDFs}\right.$, $\mathrm{H}_{7} \mathrm{CDFs}$, OCDF), and 2,3,7,8-TCDD. This type of determination is often incorrectly termed a total homolog determination. Although "homolog" is still used today to refer to dioxins or furans that have different numbers of chlorine atom substituents, the chlorinated dioxin or furan series are not homologous, because the different members of the series are not formed by adding the same structural

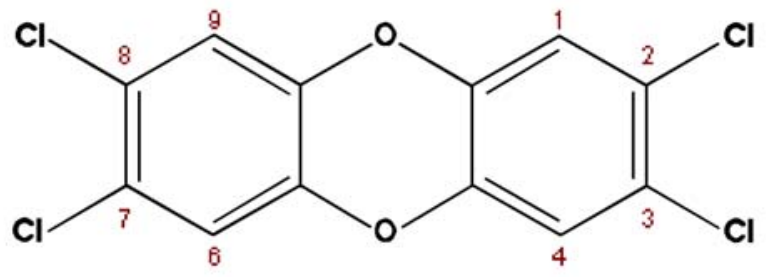

\section{2,3,7,8-Tetrachlorodibenzo-p-dioxin}

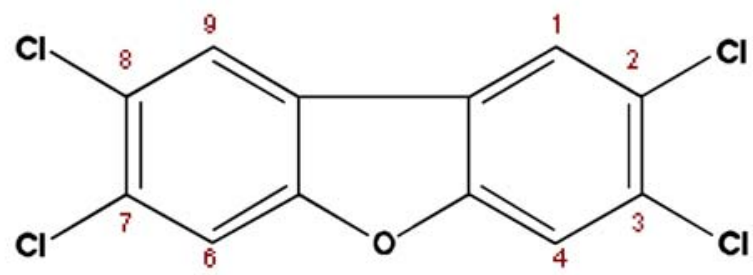

2,3,7,8-Tetrachlorodibenzofuran

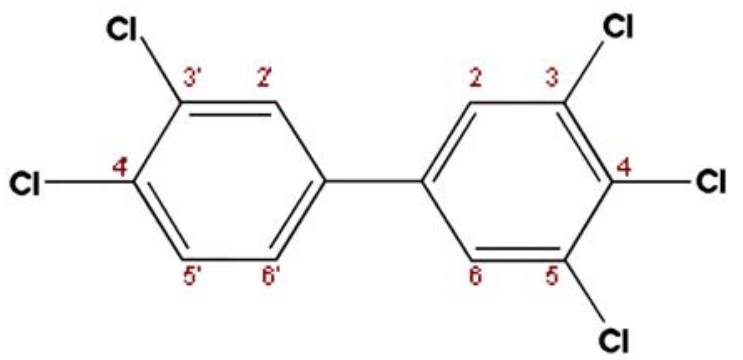

3,3',4,4',5-Pentachlorobiphenyl (PCB126)

Fig. 1 Basic structures of the chlorinated dibenzo-p-dioxins (dioxins), chlorinated dibenzofurans (furans) and polychlorinated biphenyls (PCBs). For the dioxins and furans, congeners with chlorine substitution at the $2,3,7$ and 8 positions are considered toxic. Of the 75 possible dioxin and 135 possible furan structures, only 17 have $2,3,7,8$-substitution

unit $(\mathrm{Cl}$ atom), but by substituting $\mathrm{Cl}$ for $\mathrm{H}$ in higher members of these series. The various chlorinated dioxins are correctly termed "congeners" (members of a like series), as are the chlorinated dibenzofurans.

It was clear over 30 years ago that gas chromatographymass spectrometry (GC-MS) was the instrumental method of choice for dioxin and furan determinations. The great tunable selectivity of mass spectrometry achieved by the ability to monitor specific characteristic ions in the mass spectrum of a compound combined with the retention timematching ability of a gas chromatogram made GC-MS far superior to other detection systems. Even with the use of GC-MS, the exceptionally great toxicity of 2,3,7,8-TCDD meant that equally exceptionally low detection limits were required for this compound in real environmental samples. At such DLs as parts-per-trillion (ppt:10 $0^{-12}$ g 2,3,7,8TCDD per g of sample) or parts-per-quadrillion (ppq: $10^{-15} \mathrm{~g}$ $2,3,7,8$-TCDD per $g$ of sample), the principal barrier to 
Table 1 World Health Organization toxic equivalent factors (TEFs) for humans/mammals, fish and birds [37]

\begin{tabular}{|c|c|c|c|}
\hline Congener & Humans/Mammals & Fish & Birds \\
\hline 2,3,7,8-Tetrachlorodibenzo- $p$-dioxin (TCDD) & 1 & 1 & 1 \\
\hline 1,2,3,7,8-Pentachlorodibenzo- $p$-dioxin (PeCDD) & 1 & 1 & 1 \\
\hline 1,2,3,4,7,8-Hexachlorodibenzo- $p$-dioxin (HxCDD) & 0.1 & 0.5 & 0.05 \\
\hline 1,2,3,6,7,8-Hexachlorodibenzo- $p$-dioxin (HxCDD) & 0.1 & 0.1 & 0.01 \\
\hline 1,2,3,7,8,9-Hexachlorodibenzo- $p$-dioxin (HxCDD) & 0.1 & 0.1 & 0.1 \\
\hline 1,2,3,4,6,7,8-Heptachlorodibenzo- $p$-dioxin (HpCDD) & 0.01 & 0.001 & $<0.001$ \\
\hline 1,2,3,4,5,6,7,8-Octachlorodibenzo- $p$-dioxin (OCDD) & 0.0001 & $<0.0001$ & 0.001 \\
\hline 2,3,7,8-Tetrachlorodibenzofuran (TCDF) & 0.1 & 0.05 & 1 \\
\hline 1,2,3,7,8-Pentachlorodibenzofuran (PeCDF) & 0.05 & 0.05 & 0.1 \\
\hline 2,3,4,7,8-Pentachlorodibenzofuran (PeCDF) & 0.5 & 0.5 & 1 \\
\hline 1,2,3,4,7,8-Hexachlorodibenzofuran (HxCDF) & 0.1 & 0.1 & 0.1 \\
\hline 1,2,3,6,7,8-Hexachlorodibenzofuran (HxCDF) & 0.1 & 0.1 & 0.1 \\
\hline 1,2,3,7,8,9-Hexachlorodibenzofuran (HxCDF) & 0.1 & 0.1 & 0.1 \\
\hline 2,3,4,6,7,8-Hexachlorodibenzofuran (HxCDF) & 0.1 & 0.1 & 0.1 \\
\hline 1,2,3,4,6,7,8-Heptachlorodibenzofuran (HpCDF) & 0.01 & 0.01 & 0.01 \\
\hline 1,2,3,4,7,8,9-Heptachlorodibenzofuran (HpCDF) & 0.01 & 0.01 & 0.01 \\
\hline 1,2,3,4,5,6,7,8-Octachlorodibenzofuran (OCDF) & 0.0001 & $<0.0001$ & 0.001 \\
\hline 3,4,4',5-Tetrachlorobiphenyl (PCB 81) & 0.0001 & 0.0005 & 0.1 \\
\hline 3,3',4',4'-Tetrachlorobiphenyl (PCB 77) & 0.0001 & 0.0001 & 0.05 \\
\hline 2',3,4,4',5-Pentachlorobiphenyl (PCB 123) & 0.0001 & 0.000005 & 0.00001 \\
\hline 2,3',4,4',5-Pentachlorobiphenyl (PCB 118) & 0.0001 & $<0.000005$ & 0.00001 \\
\hline 2,3,4,4',5-Pentachlorobiphenyl (PCB 114) & 0.0005 & $<0.000005$ & 0.0001 \\
\hline 2,3,3',4,4'-Pentachlorobiphenyl (PCB 105) & 0.0001 & $<0.000005$ & 0.0001 \\
\hline 3,3',4,4',5-Pentachlorobiphenyl (PCB 126) & 0.1 & 0.005 & 0.1 \\
\hline 2,3',4,4',5,5'-Hexachlorobiphenyl (PCB 167) & 0.00001 & $<0.000005$ & 0.00001 \\
\hline 2,3,3',4,4',5-Hexachlorobiphenyl (PCB 156) & 0.0005 & $<0.000005$ & 0.0001 \\
\hline 2,3,3',4,4',5'-Hexachlorobiphenyl (PCB 157) & 0.0005 & $<0.000005$ & 0.0001 \\
\hline 3,3',4,4',5,5'-Hexachlorobiphenyl (PCB 169) & 0.01 & 0.00005 & 0.001 \\
\hline $2,3,3^{\prime}, 4,4^{\prime}, 5,5^{\prime}$-Heptachlorobiphenyl (PCB 189) & 0.0001 & $<0.000005$ & 0.00001 \\
\hline
\end{tabular}

successful analysis of samples was the separation of TCDD from the bulk sample matrix and from all other organic chemicals in the matrix. The keys to success in this endeavor were the number of separation steps in the entire analytical scheme, and their effectiveness. These separation steps included the following:

- Representative sampling (not included in this review);

- Separation of TCDD from the sample matrix (extraction); transfer of TCDD to an appropriate organic solvent;

- Separation of TCDD from all other organic coextractives (clean-up; can involve several distinct steps);

- Separation of TCDD from other relatively nontoxic tetrachlorinated dioxin isomers (gas chromatography);

- Separation and recording of characteristic TCDD molecular fragments using a mass spectrometer.

Although an impressive degree of optimization of each of these steps has occurred over the past decade, this basic approach was formulated in the mid-1970s. A paper published in 1973 showed how high-resolution mass spectrometry (HRMS) was used to determine 2,3,7,8TCDD in various sample types at the $1.0 \mathrm{ppt}$ DL [7].
Modern dioxin/furan determination

In recent years, methods have built on the early developments referred to above, and have achieved a high degree of sophistication and greatly improved accuracy and precision. The various stages of development of dioxin/ furan determination can be generically described as follows:

1970 s to $1980 \mathrm{~s}$ The principal concern was to ensure correct identification of TCDD; the majority of analyses reported total concentrations of dioxin and furan (tetrachlorinated to octachlorinated) congener groups, and/or 2,3,7,8-TCDD; very few reliable analytical standards or certified reference materials were available; few laboratories worldwide could perform this work;

1980s to 1990s Fused silica open tubular GC columns predominantly used for this application; quality control for GC-MS methods enhanced greatly by the use of the isotope-dilution technique; GC-HRMS was accepted as "gold standard" method; introduction of "toxic equivalent factors (TEFs)" made it imperative to improve speciation of all dioxins/furans with chlorine substitution at the 2,3,7 
and 8 ring positions; $10-20$ or so laboratories worldwide were proficient in this work;

$1990 s$ to $2000 s{ }^{13} \mathrm{C}$-isotope labeled standards of all 2,3,7,8-substituted dioxins/furans available, as well as wide array of certified or consensus real-matrix reference materials; reliable methods available for precise, accurate isomer-specific determination of all 2,3,7,8-substituted dioxins/furans at ppt to ppq concentrations in virtually any sample matrix; most results for regulatory work reported as "toxic equivalent quantity (TEQ)" concentrations; coplanar PCBs began to be included in TEQ calculations; $>100$ laboratories worldwide are proficient in this work;

Future focus Detection limits are low enough for most regulatory purposes, but may need to be pushed lower for bioaccumulation studies and determination of subtle effects from these compounds like changes in sex ratios; future improvements will be difficult due to ubiquitous background levels of these compounds and potentially interfering compounds at such low DLs; biggest challenges could be to lower the high cost and to improve the speed of analysis; bioanalytical methods may help, but are still of limited success after over 20 years of development; multidimensional orthogonal methods, such as two-dimensional chromatography $(\mathrm{GC} \times \mathrm{GC}, \mathrm{LC} \times \mathrm{GC})$ or tandem mass spectrometry (MS/MS), may increase selectivity and also reduce detection limits, allowing for an increased number of analytes in a single analysis.

\section{Toxicology and TEFs}

Dioxin-like halogenated aromatic hydrocarbons (HAHs) provoke an extraordinarily broad spectrum of toxic effects in vertebrate laboratory animals. Exposure to a few micrograms per $\mathrm{kg}$ body weight of the most potent congener, 2,3,7,8-TCDD, leads to (among numerous effects) loss of body weight, liver necrosis, immune impairment, reproductive toxicity, teratogenesis and cancer in many laboratory species [8-11]. A single TCDD dose of $1 \mu \mathrm{g} / \mathrm{kg}$ is lethal to guinea pigs. In human populations exposed to HAHs by occupation or by industrial accident, the reported adverse health effects include reproductive disorders [12], developmental toxicity [13, 14], insulin insensitivity [15] and cancer [16, 17]. However, there is considerable controversy and uncertainty about the degree of risk to human health from dioxin-like compounds, particularly regarding cancer risk $[18,19]$. There is no question, however, that TCDD can cause the severe skin disorder known as chloracne in some highly-exposed individuals [20]; chloracne is considered to be the "hallmark" of human dioxin toxicity.

If we understand the mechanism by which a chemical produces its toxic effects, we are in a better position to assess the risk that the chemical poses to humans and to other species. Extensive research over the past quarter- century has demonstrated that all major toxic effects of dioxin-like chemicals are mediated by their binding to a soluble intracellular protein, the aryl hydrocarbon receptor (AHR) [21-23]. The AHR's normal function is to regulate transcription of multiple genes that are important in development, physiologic function and adaptive responses to xenobiotic chemicals [24, 25]. Dioxin-like chemicals appear to exert their toxicity by dysregulating expression of key genes that are under control of the AH receptor [23].

Throughout most of its history, the science of toxicology has needed to cope with the effects of only one chemical at a time. HAHs present an unusual challenge to the toxicologist because "real-world" HAH exposure is not to single compounds; rather, HAH exposure involves complex mixtures of dozens to hundreds of congeners from the dioxins ( 75 possible), furans (135 possible) and PCBs (209 possible).

The fact that dioxin-like compounds work through a common mechanism, the AHR [10, 23], fostered development of the "toxic equivalent factors" (TEF) approach to assessing the toxicological potency of HAH mixtures [26]. The TEF approach is based on a proposal first made by the Ontario Ministry of the Environment in 1984 [27]. In this approach, 2,3,7,8-TCDD, the most potent congener, is assigned a TEF of 1.0, and all other congeners are assigned TEFs that reflect their toxic potency relative to that of TCDD. For example, 2,3,7,8-tetrachlorodibenzofuran and 3,3',4,4',5-pentachlorobiphenyl (PCB126) each are assigned a TEF of 0.1 , whereas octachlorodioxin has a TEF of 0.0001 , reflecting its very low toxicity compared with that of 2,3,7,8-TCDD. The toxicity of a mixture is stated as TEQ (TCDD equivalents) and is assumed to be equal to the sum of the concentration of individual congeners multiplied by their potencies $\left(\mathrm{TEF}_{\mathrm{i}}\right)$ [28]:

$$
\begin{aligned}
\mathrm{TEQ}=\Sigma\left[\mathrm{PCDD}_{\mathrm{i}} \times \mathrm{TEF}_{\mathrm{i}}\right] & +\Sigma\left[\mathrm{PCDF}_{\mathrm{i}} \times \mathrm{TEF}_{\mathrm{i}}\right] \\
& +\Sigma\left[\mathrm{PCB}_{\mathrm{i}} \times \mathrm{TEF}_{\mathrm{i}}\right]
\end{aligned}
$$

Note that the TEF approach applies only to agents that are dioxin-like in that their toxic effects are mediated by the AHR. Noncoplanar PCBs have different mechanisms of action and are not accommodated in the TEF approach. For simplicity it is assumed that all dioxin-like congeners produce toxic responses that are qualitatively the same and that the congeners differ only in their potency to produce these adverse effects, but this simplifying assumption should not be viewed as being true in a literal sense. It is true, however, that the toxic potencies of congeners within the dioxin-like category vary over several orders of magnitude.

By definition, in order to calculate the total TEQ of a mixture we need to know the concentration of each dioxinlike component in the mixture. Hence the need for sensitive and reliable congener-specific chemical analyses. Regulatory decisions and risk management need to proceed even in the absence of perfect information. The TEQ approach is 
a useful simplifying strategy to allow risk assessment to move forward for exposures that involve complex mixtures, but it includes several assumptions [28-30]. There are two key issues:

1. What is the proper TEF for each congener?

2. What is the predominant mode of interaction between congeners when present in a mixture?

The first question-what is the proper TEF for a particular congener? - has not been as straightforward as was initially envisioned. The main difficulty is that the estimated relative potency (REP) of congeners differs depending on what endpoint is measured, in what tissue and in what animal species. The relative potency estimates that underlie TEFs are derived from highly heterogeneous data sets [27] that require judgment and interpretation rather than providing numbers that can simply be plugged into an equation. The TEFs currently used in risk assessment are not based on a single biological endpoint. Rather, current TEFs were assigned in 1997 by an expert panel of the World Health Organization (WHO) who took into account multiple biochemical and toxicologic endpoints. The highest weight was given to studies done in mammalian systems in vivo (rather than in vitro), to chronic studies (rather than acute), and to studies that measured a toxic outcome (rather than a biochemical response). The relative potency estimates and resulting TEFs derived by the WHO panel are now undergoing refinement [27].

The second question-how do components in a complex HAH mixture interact? - is also not easily answered. The central premise in the equation used to calculate TEQ is that the toxic effects of components in the mixture are additive; i.e., that the overall toxicity of the mixture is the sum of the concentration of each congener multiplied by its
TEF. There is experimental evidence to support the assumption of additivity $[31,32]$. However, principles of receptor pharmacology predict that compounds which compete for the same receptor site may antagonize each other so that the overall response is less than additive. From the viewpoint of risk, of course it would be desirable for the toxicity of mixtures to be less than the sum of toxicities of individual components. Several studies have found antagonism between chemicals that act at the $\mathrm{AH}$ receptor site $[29,33,34]$ - in other words, the standard TEQ approach in these circumstances overestimates the toxic potency of the mixture. It also is possible that components in a mixture might synergize to produce a response that is greater than that predicted by the additive model. Fortunately there is limited evidence of such an unwanted scenario for the toxicity of dioxin-like chemicals [35]

It is important to recognize that TEF values for some congeners can differ by tenfold or more among different animal species. For example, the TEF for 1,2,3,4,7,8hexachlorodibenzo- $p$-dioxin is ten-fold higher in fish than in birds (Table 1) [37]. When assessing risks to wildlife from exposure to HAH mixtures, we need to be aware that TEF values for most HAH congeners have been rigorously determined within only a very few nonhuman, nonrodent species. Risk estimates may be erroneous or misleading if TEF values from one animal species are assumed to be the same for other species.

Congener-specific chemical assays for dioxin-like compounds have dramatically improved in sensitivity and reliability over the past two decades. Nonetheless, such assays remain expensive. Therefore, economical alternatives have been sought which would permit estimates of the potential toxicity of mixtures to be made. Bioassays such as the "chemically activated luciferase gene expression" assay (CALUX) assess the overall biological activity of a mixture

Table 2 Regulatory methods for the analysis of dioxins, furans and DLPCBs

\begin{tabular}{ll}
\hline Method & Analytes/Comments \\
\hline USEPA 1613 & $\begin{array}{c}\text { Seventeen 2,3,7,8-substituted dioxins and furans and congener group totals in water and wastewater. Uses [38] } \\
\text { isotope dilution-GC-HRMS }\end{array}$ \\
USEPA 1668a & 209 PCB congeners. 12 WHO dioxin-like PCBs by GC-HRMS, the remaining 197 by GC-MS \\
USEPA 23 & Seventeen 2,3,7,8-substituted dioxins and furans and congener group totals in incinerator stack gasses. Uses [45] \\
& isotope dilution-GC-HRMS \\
USEPA 8290 & Seventeen 2,3,7,8-substituted dioxins and furans and congener group totals in materials and waste. Uses \\
[SW-846) & [46] \\
ISO 18073 & Equivalent to USEPA 1613, also allows GC-MS as an alternate detection method \\
ISO 17858 & Twelve WHO dioxin-like PCBs in environmental matrices by GC-HRMS \\
EN 1948 & Seventeen 2,3,7,8-substituted dioxins and furans and congener group totals in stationary sources by isotope [49] \\
dilution-GC-HRMS & Seventeen 2,3,7,8-substituted dioxins and furans including congener group totals and 12 WHO dioxin-like [50] \\
MOE 3418 & PCBs by GC-HRMS. Uses isotope dilution-GC-HRMS \\
ENVCAN & Seventeen 2,3,7,8-substituted dioxins and furans and congener group totals in pulp and paper effluents by [51] \\
1/RM/19 & isotope dilution-GC-HRMS \\
JIS K0312 & Seventeen 2,3,7,8-substituted dioxins and furans including congener group totals in wastewater by isotope [52] \\
JIS K0311 & Silution-GC-HRMS \\
& by isotope dilution-GC-HRMS \\
\hline
\end{tabular}


and do not require knowledge of the identity or concentration of individual components of that mixture. The CALUX cell bioassay is predicated on the AHR being the mediator of toxicity. It tests sample extracts for their ability to increase expression of a luciferase reporter gene that is under the control of the $\mathrm{AH}$ receptor and thereby provides an index to the total equivalents of dioxin-like chemicals (CALUX-TEQ). As with chemical assays, sample extraction and sample clean-up are critical stages in bioassays such as CALUX. For some purposes, bioassays such as CALUX can provide a useful complement or alternative to congener-specific chemical assays. See Windal et al. [36] for an excellent review of the properties and applications of CALUX.

\section{Modern methods of analysis}

The "gold standard" for the analysis of dioxins and furans uses classical extraction techniques such as Soxhlet [38], liquid/liquid extraction [38], solid-phase extraction (SPE) $[40,41]$, or the more recent pressurized fluid extraction [42-44]. Once the extract has been transferred to a suitable solvent, a three-stage (silica, alumina and carbon) opencolumn clean-up is followed by GC-HRMS (employing isotope dilution) as the analytical finish. Minor variations on this method have been used since the late 1970s and it continues to be the method of choice for regulatory and legal purposes. A number of these methods are listed in Table 2.

Overview of analytical process The generic steps of the analytical process were listed above in the "Introduction", except for the objectives, and data evaluation. These are mentioned here because of their great importance, but will not be discussed in detail. It is important to be clear about the objectives of dioxin/furan/DLPCBs determinations, because there are several choices in methodologyassociated with substantially different costs - that generate data of differing precision and accuracy [54]. For example, for rapid on-site analysis for the purpose of directing a site remediation project, a substantially different methodology can be used compared to that required for legal action. Data evaluation will also not be discussed, but the authors would simply like to make the point that in spite of significant advances in software and data systems, the low-level determination of dioxins, furans and DLPCBs still requires detailed manual examination by experienced analysts of the raw data generated by GC-HRMS systems. A discussion of sampling is beyond the intended scope of this review, but it may often be the case that the imprecision of sampling is similar to or significantly greater than the combined imprecision of the remaining steps of the analytical process.

Sample extraction methods See [55]. Classical extraction techniques like liquid/liquid extraction and Soxhlet extraction are described in detail in the methods listed in Table 2 and will not be addressed in this review. A number
Table 3 Alternative extraction techniques

\begin{tabular}{lll}
\hline Matrix & Technique & Reference \\
\hline Soil/sediment/solid & PLE & {$[42-44]$} \\
& SFE & {$[58]$} \\
& MASE & {$[59]$} \\
Aqueous & SPMD, passive sampling & {$[60,61]$} \\
& SPE & {$[40,41]$} \\
Air & Swipe/biofilms & {$[62]$} \\
& Passive sampling & {$[63,64]$} \\
\hline
\end{tabular}

of alternative extraction techniques are summarized in Table 3. Supercritical fluid extraction (SFE) uses a gas above the critical point (the combination of temperature and pressure where the gas has liquid-like properties enabling enhanced extraction capability) to extract analytes from the matrix. The main advantage with SFE is that the extracting gas can be evaporated and so solvent disposal is not required. SFE behaves significantly differently to classical solvent extraction and recoveries can be reduced or enhanced. Pressurized liquid extraction (PLE), also known as accelerated solvent extraction (ASE) evolved from SFE. Solvents were added to SFE extractions as modifiers in order to mimic classical liquid extractions. SFE without extraction gas and only solvent modifier best matched classical extraction recoveries. This led to the development of PLE. Microwave-assisted extraction (MAE or MASE) uses closed vessels to increase pressure and extraction efficiency. Polar solvents like acetone or water are required to supply heat for extraction. Sun et al. [56] reported the analysis of wet samples by MAE, indicating that significant time was saved by the reduced sample drying requirements.

Solid-phase extraction can significantly reduce analysis times and solvent usage for the extraction of water and waste water samples, even with significant particulate loadings [40]. Particles collected on $\mathrm{C}_{18}$ extraction disks can be extracted quantitatively without Soxhlet or PLE extraction. Water samples have also been analyzed using semi-permeable membrane devices (SPMD). SPMD sampling is a form of passive sampling that can be used for water, air or sediments. Namiesnik [57] has recently reviewed passive sampling techniques in environmental samples. Passive sampling is based on the free flow of analytes from the sampling medium to the collecting medium. This technique eliminates the requirement for power, and is a composite sampling procedure that can reduce analysis cost because of reduced sampling events and analyte loss during shipping and storage as the analyte is on a trapping medium. Swipe tests of biofilms on surfaces can also be used to monitor ambient conditions, especially after fires or from fugitive emissions.

Sample extract clean-up methods Sample preparation of dioxin extracts is one of the most challenging in analytical chemistry. Many coextractable and potentially interfering compounds present in the raw extract must be removed in order provide maximum concentration factors $\left(10^{6}\right.$ to $\left.10^{8}\right)$ 
to meet DLs. A number of classical adsorbents can be used, including silica, alumina, Florisil and carbon. Most current procedures are based on the "Dow" [65] and "Smith-Stallings" [66] procedures. These procedures are described in detail in the references given in Table 2 above. Disposable $\mathrm{C}_{18}$ /silica SPE cartridges [67] have been used for rapid clean-up of biological materials.

The analysis of dioxins is very costly and timeconsuming. Over the past 20 years, a number of modifications have been made to automate sample extraction and sample extract preparation to reduce analysis times and to attempt to reduce costs. Focant [42] has recently reviewed the automated sample preparation of biological samples. Multicolumn automated systems like the FMS (fluid management system) automated Power Prep system were developed to prepare human serum extracts, and have subsequently been used in a number of applications, including biota, water and food. Interchangeable cartridges (silica, alumina, carbon) can be used in different configurations $[68,69]$. The addition of a PLE interface preceding the Power Prep enables the sample to be extracted and cleaned in the same automated run. Food samples (three) have been extracted, cleaned and analyzed in ten hours using this system [68]. An alternate method reported by Thal [70] used an automated gel permeation chromatographic (GPC)/carbon system. The GPC removes coextractables like lipids from the extract, which is then processed on activated carbon to separate the planar from the nonplanar compounds. This is based on a system reported by Norstrom et al. [71]. Van Beuzekom used an automated microwave solvent extraction system (MASE) coupled to a liquid chromatograph for the analysis of fine particles from fire emissions [59]. Nording [72] was able to modify a PLE extraction cell to insert the sample matrix above AX21 carbon packing in order to perform extraction and clean-up in the cell as a screening method. Results compared well with GC/HRMS confirmatory analysis.

Sample preparation schemes are developed to remove most interferences from the sample extract. Unfortunately, because many compounds have similar physical and chemical properties, a considerable number of interferences often still remain in the cleaned sample extracts. Some examples of interferences on selected DLPCBs using a 5\% phenyl column are listed below [50].

\begin{tabular}{ll} 
PCB congener & Potential interference \\
PCB 81 & PCB 87 \\
PCB 77 & PCB 110 \\
PCB 123 & PCB 149 \\
PCB 126 & PCBs 178 and 129 \\
PCB 156 & PCB 171 \\
PCB 157 & PCB 201 \\
\hline
\end{tabular}

Gas chromatography columns and methods PCB interferences can be eliminated or removed physically as in MOE Method 3418, or by analyzing extracts on multiple columns (US EPA Method 1668). A number of analyte- specific columns have been developed to reduce both dioxin and PCB interferences and reduce the need for multicolumn analysis. The standard 5\% phenyl columns exhibit multiple coelutions for PCBs (see above) and dioxins. The Rtx-Dioxin2 [73, 74] column has very few interfering compounds. BPX-DXN exhibits very low bleed and enhanced separation over 5\% phenyl columns [75]. Liquid crystal columns [76, 77] provide outstanding separation for 2,3,7,8-substituted dioxins and furans, but suffer from high bleed and low column temperature maximum limits.

Fast GC is accomplished by reducing inner column diameters and phase thickness. The number of theoretical plates per meter is increased significantly. If the phase ratio (inner column diameters/phase thickness) remains constant, the chromatography does not change and separations in micobore columns can be achieved much faster because of the shorter column lengths [78-80]. MacPherson [81] reported the use of simultaneous dual parallel column analysis of dioxins/furans/coplanar PCBs (Fraction A) on a $40 \mathrm{~m} \mathrm{DB}-5$ column and ortho-substituted PCBs (Fraction B) on a 20 m DB-5 column in under $45 \mathrm{~min}$. Extracts were separated using activated carbon/ silica. This combination can meet GC-HRMS QC specifications (e.g., US EPA 1613).

Two-dimensional chromatography [82-84] has been investigated by a number of researchers in order to solve coelution issues from single-column analysis. A number of column combinations have been used to solve coelutions for dioxins and PCBs $[85,86]$. $\mathrm{GC} \times \mathrm{GC}$ produces very narrow peaks that can provide significantly enhanced sensitivity, increased column capacity and reduced analysis times. It requires fast detection which pushes the limits of HRMS capability. A number of applications have been reported using TOFMS $[85,86]$, ECD [87, 88] ITMS [89] LRMS [90] and HRMS [178] as detectors for $\mathrm{GC} \times \mathrm{GC}$. The potential for enhanced chromatographic selectivity and reduced analysis times has created a lot of interest in this area.

Mass spectrometry detection methods See [91, 92]. HRMS has been the definitive detection method since the beginning of dioxin analysis (in 1973) [7]. Many detection techniques have been investigated [93], but none can match the selectivity and sensitivity of HRMS [94-97]. Tandem mass spectrometry as hybrid/MS [98], triple quadrupole MS/MS $[99,100]$ or ion trap MS/MS $[85,101]$ have been used to analyze dioxins and furans. MS/MS is more selective than HRMS for dioxins in most cases, because the parent molecule loses $\mathrm{COCl}$, weighing $63 \mathrm{amu}$. No other halogenated organic has been shown to fragment in this way. The sensitivities of MS/MS instruments are typically less than HRMS, but with slight adjustments to sample size and final extract volume, GC-HRMS QC specifications can typically be achieved. Eppe [102] achieved 5:1 signal to noise with the injection of $200 \mathrm{fg}$ of 2,3,7,8-TCDD. Unfortunately, the enhanced selectivity observed with MS/MS analysis of dioxins is not experienced with PCBs. The loss of $\mathrm{Cl}_{2}$ from the parent molecule is not 
unique to polychlorinated compounds and typically interfering peaks can be detected in the MS/MS chromatograms of PCBs.

Electron ionization (EI) with reduced electron energy $(\sim 35 \mathrm{eV})$ is the typical method of ionization used in dioxin/DLPCB analysis. The reduced electron energy focuses ion current towards the molecular ion, reduces the number of fragment ions, and subsequently enhances sensitivity. Negative ion chemical ionization (NICI or $\mathrm{NCI}$ ) is also a low-energy ionization technique [103], which produces mass spectra with little fragmentation, resulting in enhanced parent ion signals. NCI analysis of dioxins, furans and PCBs has recently been investigated by Chernestsova using a variety of reagent gases [104]. Detection limits for PCBs are equivalent to or lower than for EI with a trend of increasing signal strength with increasing degree of chlorination. Similar results were observed for dioxins, except for 2,3,7,8-TCDD which is up to two orders of magnitude less sensitive in NCI than EI [105]. The molecular anion of 2,3,7,8-TCDD readily fragments to the chloride anion. Unfortunately, many other coextractables also fragment to the chloride anion, significantly reducing selectivity, and as a result NCI has not been used routinely for the analysis of dioxins and furans.

Alternate methods of analysis Due to the challenging sample preparation, selectivity and ultra-low detection requirements, the cost of dioxin analysis is much higher than any other analytical method. Researchers have been searching for alternate low-cost methods for years. Immunoassay [106-110] and bioassay [111-114] methods can reduce costs by $50 \%$ or more and have been used to analyze food samples and samples collected from hazardous sites where very fast analysis is needed. The relative potencies for bioassays and cross-reactivities for immunoassay methods roughly mimic toxic equivalent factors used in mass spectrometric methods, enabling results to be obtained in TEQ directly. The main disadvantages of these types of methods are the inability to use labeled internal standards to correct for recovery and the determination of congener profiles for source apportionment. Spiked samples, similar to standard addition quantitative analysis, permit recoveries to be estimated, overcoming this problem. Recent publications have shown that bio/immuno methods compare well with

Table 4 Uncertainty of dioxin, furan and DLPCB measurements in selected matrices, reported in percent (\%) [127]

\begin{tabular}{|c|c|c|c|c|c|}
\hline Parameter & CAS No. & Soil $N=59$ & Biota $N=34$ & Water $N=35$ & Veg $N=12$ \\
\hline 2,3,7,8-TCDD & $1746-01-6$ & 20 & 26 & 19 & 21 \\
\hline $1,2,3,7,8-\mathrm{PeCDD}$ & $40321-76-4$ & 25 & 17 & 14 & 21 \\
\hline 1,2,3,4,7,8-HxCDD & $39227-28-6$ & 15 & 13 & 18 & 16 \\
\hline 1,2,3,6,7,8-HxCDD & $57653-85-7$ & 17 & 18 & 30 & 29 \\
\hline 1,2,3,7,8,9-HxCDD & $19408-74-3$ & 19 & 21 & 31 & 24 \\
\hline 1,2,3,4,6,7,8-HpCDD & $35822-46-9$ & 12 & 22 & 38 & 26 \\
\hline $1,2,3,4,5,6,7,8-\mathrm{OCDD}$ & $3268-87-9$ & 15 & 18 & 31 & 20 \\
\hline $2,3,7,8-\mathrm{TCDF}$ & $51207-31-9$ & 15 & 23 & 37 & 23 \\
\hline $1,2,3,7,8-\mathrm{PeCDF}$ & $57117-41-6$ & 15 & 20 & 32 & 23 \\
\hline 2,3,4,7,8-PeCDF & $57117-31-4$ & 17 & 16 & 31 & 27 \\
\hline $1,2,3,4,7,8-\mathrm{HxCDF}$ & $70648-26-9$ & 13 & 15 & 29 & 17 \\
\hline $1,2,3,6,7,8-\mathrm{HxCDF}$ & $57117-44-9$ & 14 & 13 & 34 & 21 \\
\hline $1,2,3,7,8,9-\mathrm{HxCDF}$ & $72918-21-9$ & 16 & 13 & 35 & 22 \\
\hline $2,3,4,6,7,8-\mathrm{HxCDF}$ & $60851-34-5$ & 21 & 16 & 31 & 24 \\
\hline $1,2,3,4,6,7,8-\mathrm{HpCDF}$ & $67562-39-4$ & 16 & 13 & 32 & 19 \\
\hline $1,2,3,4,7,8,9-\mathrm{HpCDF}$ & $55672-89-2$ & 11 & 15 & 37 & 16 \\
\hline \multirow[t]{2}{*}{$1,2,3,4,5,6,7,8-\mathrm{OCDF}$} & $39001-02-0$ & 21 & 27 & 15 & 33 \\
\hline & & $N=56$ & $N=26$ & $N=10$ & \\
\hline РCB 77 3,3'4,4'-ТCB & $32598-13-3$ & 24 & 14 & 14 & \\
\hline РCВ $813,4,4,, 5-\mathrm{TCB}$ & $70362-50-4$ & 23 & 16 & 9 & \\
\hline РCB 105 2,3,3,'4,4'-PeCB & $32598-14-4$ & 28 & 71 & 27 & \\
\hline РCВ 114 2,3',4,4',5-РeCB & $74472-37-0$ & 19 & 17 & 17 & \\
\hline РCB 118 2,3',4,4',5-PeCB & $31508-00-6$ & 25 & 90 & 49 & \\
\hline РCВ 123 2',3,4,4',5-PeCB & $65510-44-3$ & 23 & 22 & 14 & \\
\hline РCB 126 3,3',4,4',5-PeCB & $57465-28-8$ & 28 & 15 & 16 & \\
\hline РСВ 156 2,3,3',4,4',5-НxCB & $38380-08-4$ & 19 & 23 & 9 & \\
\hline РCВ 157 2,3,3',4,4',5'-НxCB & $69782-90-7$ & 32 & 22 & 10 & \\
\hline РCВ 167 2,3',4,4',5,5'-HxCB & $52663-72-6$ & 21 & 12 & 13 & \\
\hline РСВ 169 3,3',4,4',5,5'-НxCB & $32774-16-6$ & 25 & 15 & 11 & \\
\hline РCВ 189 2,3,3',4,4',5,5'-НpCВ & $39635-31-9$ & 14 & 17 & 12 & \\
\hline
\end{tabular}


standard GC/HRMS methods in terms of sensitivity, selectivity and accuracy [115-118].

Most analytical laboratories are now being challenged to analyze for multiple analyte groups, including polybrominated diphenyl ethers (PBDEs), polychlorinated naphthalenes, as well as dioxins, furans and DLPCBs. Multicomponent methods have been developed for a variety of matrices [119-122] in order to reduce costs accrued by multiple separate extractions, clean-up and instrumental analyses. Analysts must exercise caution when adding additional analyte groups to existing methods. Modifying methods to increase the number of analytes can result in compromised (less than ideal) conditions for a number of analytes, giving rise to potential interferences and/or reduced recoveries for these analytes.

Quality control and data reporting Dioxin methods inherently include a number of quality control standards and samples. Isotope dilution (ID) methods are typically used with ${ }^{13} \mathrm{C}$-labeled internal standards. ID standards are added prior to extraction, allowing correction for recovery over the multistage clean-up procedures. The isotopically labeled standards can also act as markers for the identification of native analytes in samples. As the ID standards are often added at concentrations 10-100 times those expected for the analytes, the standards can act as "carriers" to improve recoveries of analytes at ultra-trace concentrations and can offset losses due to adsorption. The isotopically enriched standards aid in method development/validation, as they can be added at various stages of the analytical process to track down problems associated with analyte recovery or method bias.

Until recently very few reference materials were available for method validation and performance evaluation. CRMs for sediments [123] and biota $[124,125]$ are now available.

Uncertainty in analytical data is an important method attribute. The calculation of uncertainty is carried out using data from a number of sources, including instrument precision, linearity, fortified matrices, MDLs, spiked samples and interlaboratory data [126]. Uncertainties for dioxins, furans and dioxin-like PCBs are listed in Table 4 in percent (\%) [127]. Uncertainties for dioxins and furans range between 15 and $20 \%$ for most analytes. The two most significant errors in the analysis are the error in the standards $( \pm 10 \%)$ quoted by the manufacturer and the error of calibration (typically $\pm 20 \%$ ) that is accepted by the analyst. Other errors, such as mass and volumetric determinations, should be less than $5 \%$. Uncertainties are elevated for water samples over soil and biota due to the greater amount of labware that contacts the sample and the influence of particles on the homogeneity of the sample. Similar levels of uncertainty are observed for dioxin-like PCBs, except for PCB 105 and 118. These congeners are typically present at background levels of 20 and $50 \mathrm{pg}$, respectively, in the sample. Analyte losses from the extraction and sample preparation steps are corrected by the isotope dilution analytical technique and should not be significantly greater than the error in the addition of the surrogate internal standard.
When assessing the overall error and/or uncertainty for determinations of dioxins and DLPCBs, two important factors are often overlooked. First, the sampling error is not investigated in many studies. This is very difficult to assess properly because it requires many more analyses to be performed, and the cost of this work is often prohibitive. Second, a growing trend is to report results as total TEQs, and sometimes the concentration data for individual congeners - used to perform the TEQ calculation-may not be reported at all. Also, more than one set of toxic factors exist, and some papers do not report which set of factors were used or the format (e.g., $\mathrm{ND}=0$, $\mathrm{ND}=1 / 2$ ) in the TEQ calculation. Baccarelli [128] has recently reviewed the reporting of TEQ values where nondetect values are used in the TEQ calculation. It should be remembered that the toxic factors used are themselves approximations, and may contribute significantly to the degree of uncertainty in the interpretation of results. Another unfortunate trend is that reconstructed chromatograms and/or congener patterns from analyses are being reported less and less. These patterns can be useful when assessing possible sources of the dioxins/DLPCBs detected.

\section{Sources, occurrence and temporal trends in PCDD/Fs}

Alcock and Jones [129] have previously reviewed the occurrence and temporal trends in PCDD/Fs in industrialized countries including Germany, the United States, Sweden, the Netherlands and the United Kingdom. This review covered trends in sediments, air, vegetation, soils, sewage sludge, livestock tissue and milk, wildlife and human tissues. The authors reported a general global temporal trend in $\mathrm{PCDD} / \mathrm{F}$ inputs to the environment; $\mathrm{PCDD} / \mathrm{F}$ contamination increased in the $1930 \mathrm{~s} / 1940 \mathrm{~s}$, reaching a maximum in the $1960 \mathrm{~s} / 1970 \mathrm{~s}$, and subsequently declined into the 1990s as a result of actions to reduce emissions. There is general agreement in the temporal trend data between European and North American studies; however, some European studies have not determined the post-1970 declines in PCDD/F contamination evident in North America. The US EPA [130] estimated a 75\% decrease in PCDD/F emissions over the period 1987-1995. Päpke [131] reported declines ranging from $50-70 \%$ for $\mathrm{PCDD} / \mathrm{F}$ levels in human adipose tissue, blood and breast milk in Germany over the period 1980-1996.

There is also now a considerable body of literature reporting the presence of preindustrial baseline trace levels of PCDD/F contamination in soils and sediments prior to the turn of the nineteenth century [132-138]. Natural sources of PCDDs/Fs can include forest fires, volcanic activity, and other natural combustion processes [139, 140]. Although natural formation of PCDD/Fs had been postulated much earlier, some previous studies may have been compromised as a result of extraneous contamination of field samples or in the laboratory $[133,135,136]$. These measurements are significant in determining the relevance of natural sources vs. anthropogenic sources in order to as- 
sess requirements for further reductions in global $\mathrm{PCDD} / \mathrm{F}$ emissions. However, it is also evident that any $\mathrm{PCDD} / \mathrm{F}$ loadings from natural sources are dwarfed by contemporary emissions from anthropogenic sources.

$\mathrm{PCDD} / \mathrm{F}$ contamination in the North American Great Lakes has been recently reviewed by Norstrom [141], including occurrence, geographical distribution and temporal trends in air, water, sediments, fish, seabirds, snapping turtles and humans. Patterns and concentrations of PCDD/Fs in sediment indicate that atmospheric inputs dominate in Lake Superior, lower Lake Michigan and Lake Erie. Inputs from the Saginaw River to Lake Huron, and from the Fox River to upper Lake Michigan, are responsible for additional PCDD/PCDF loading to these areas beyond atmospheric deposition. Lake Ontario continues to be heavily impacted by input of PCDD/Fs, particularly 2,3,7,8-TeCDD, from the Niagara River [142].

According to Alcock and Jones [129], studies of sediment cores from the Great Lakes represent the bulk of sediment temporal trend data for PCDD/Fs (e.g., [143]); sediment cores are particularly useful when studying the chronology of PCDD/F contamination (e.g., [144-147]). North American Great Lakes sediment core and biomonitoring data generally show that $\mathrm{PCDD} / \mathrm{F}$ contamination peaked in most lakes in the late 1960s to early 1970s, followed by rapid order of magnitude declines in the mid to late 1970s [144, 146-148]. The downward trend leveled off in some lakes in the 1980s, but appears to have continued after the late 1990s, presumably in response to remedial actions and reductions in $\mathrm{PCDD} / \mathrm{F}$ emissions to the atmosphere [141]. Pearson et al. [148] reported that

Fig. 2 Geographical distribution of United States and Canadian dioxin emissions for 1996. Reproduced with permission from Cohen et al. [149]

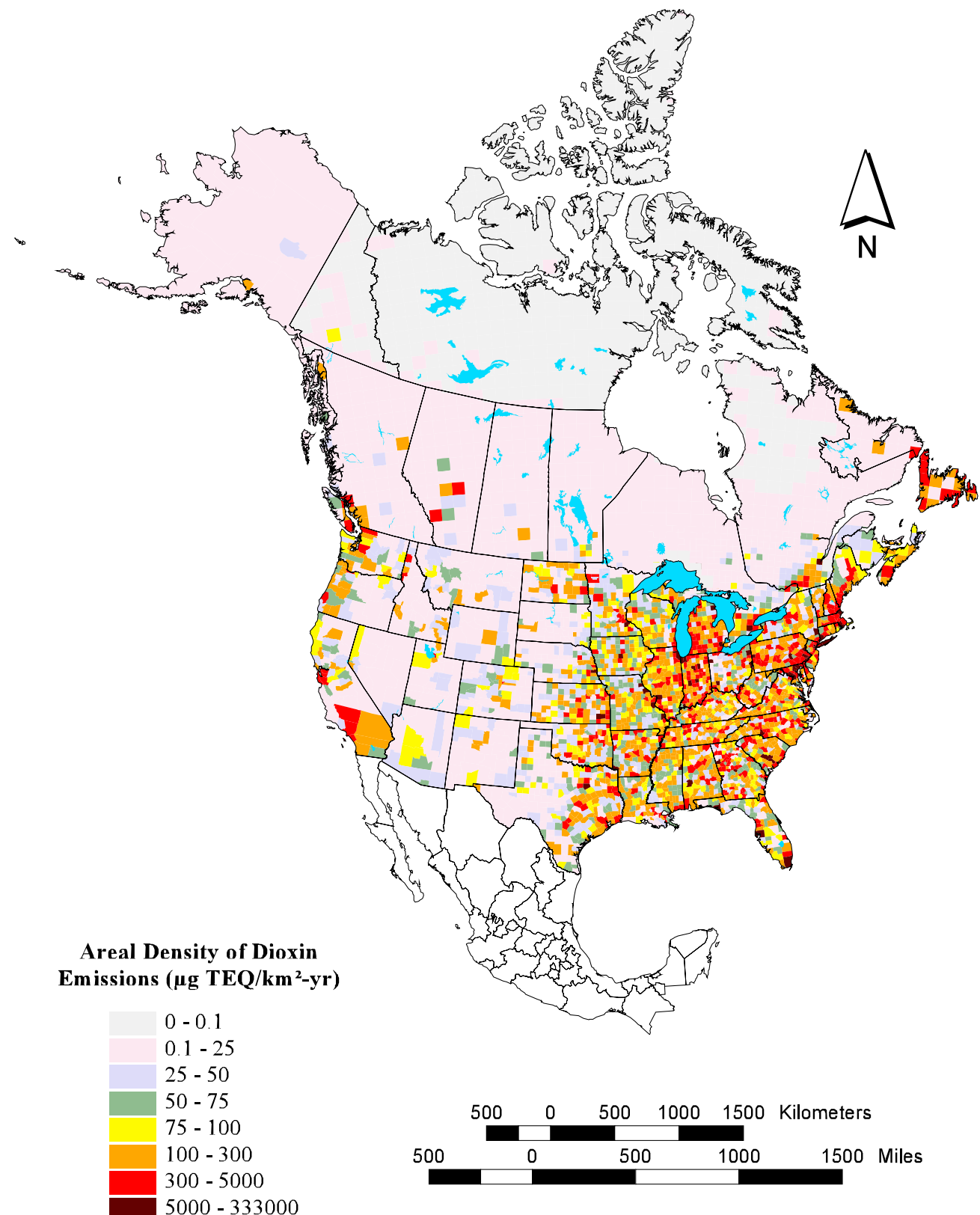


Table 5 Selected global environmental concentrations of PCDD/Fs

\begin{tabular}{|c|c|c|c|c|}
\hline Matrix & Region & Concentration Range & Reference & Remarks \\
\hline Air & Europe & $<1 \mathrm{fg} \mathrm{TEQ} / \mathrm{m}^{3}$ & & Typical rural \\
\hline Air & Europe & $15,000 \mathrm{fg} \mathrm{TEQ} / \mathrm{m}^{3}$ & & Contaminated area \\
\hline Air & Asia & $7-1,486 \mathrm{fg} \mathrm{TEQ} / \mathrm{m}^{3}$ & & \\
\hline Air & South America & $3-394 \mathrm{fg} \mathrm{TEQ} / \mathrm{m}^{3}$ & & \\
\hline Freshwater & Korea & $0.001-1.061 \mathrm{pg}$ TEQ/L & & \\
\hline Freshwater & Japan & $0.012-48 \mathrm{pg} \mathrm{TEQ} / \mathrm{L}$ & & 2,116 sites \\
\hline Seawater & Japan & $0.005-3.9 \mathrm{pg} \mathrm{TEQ} / \mathrm{m}^{3}$ & & 12 sites \\
\hline Seawater & Japan & $\mathrm{ND}-0.4 \mathrm{pg} \mathrm{TEQ} / \mathrm{m}^{3}$ & & 21 sites \\
\hline Soil & Seveso, Italy & 0.91-16 pg TEQ/g & & \\
\hline Soil & Germany & $1-5 \mathrm{pg}$ TEQ/g & {$[143]$} & Rural \\
\hline Soil & Germany & $30,000 \mathrm{pg} T E Q / g$ & {$[143]$} & Contaminated \\
\hline Soil & Germany & $10-30 \mathrm{pg} \mathrm{TEQ} / \mathrm{g}$ & {$[143]$} & Urban \\
\hline Soil & The Netherlands & $2.2-16 \mathrm{pg} \mathrm{TEQ} / \mathrm{g}$ & {$[143]$} & Rural \\
\hline Soil & The Netherlands & $98,000 \mathrm{pg} T E Q / g$ & {$[143]$} & Contaminated \\
\hline Soil & United Kingdom & $<1-20 \mathrm{pg} \mathrm{TEQ} / \mathrm{g}$ & {$[143]$} & Rural \\
\hline Soil & United Kingdom & $1,585 \mathrm{pg}$ TEQ/g & [143] & Contaminated \\
\hline Soil & New Zealand & 0.17-1.99 pg TEQ/g & {$[143]$} & Rural \\
\hline Soil & New Zealand & $260-6,670 \mathrm{pg} \mathrm{TEQ} / \mathrm{g}$ & {$[143]$} & Urban \\
\hline Sediments & Lake Ontario & $91 \mathrm{pg} \mathrm{TEQ/g}$ & {$[165]$} & Lakewide average \\
\hline Sediments & Po River & $1-11 \mathrm{pg} T E Q / \mathrm{g}$ & {$[166]$} & \\
\hline Sediments & Lake Baikal & $0.03 \mathrm{pg} \mathrm{TEQ} / \mathrm{g}$ & & \\
\hline Sediments & Japan & $16.1-50.7 \mathrm{pg} \mathrm{TEQ} / \mathrm{g}$ & & \\
\hline Sediments & New Zealand & $0.081-2.71 \mathrm{pg} \mathrm{TEQ} / \mathrm{g}$ & & \\
\hline Marine sediments & North Sea & $5.5-17.2 \mathrm{pg} \mathrm{TEQ} / \mathrm{g}$ & & \\
\hline Marine sediments & Gulf of Finland & $101,000 \mathrm{pg} \mathrm{TEQ/g}$ & & Highly contaminated \\
\hline Marine sediments & Catalan coast & $0.4-8 \mathrm{pg} \mathrm{TEQ} / \mathrm{g}$ & {$[167]$} & \\
\hline Marine sediments & Japan & $0.012-49.3 \mathrm{pg} \mathrm{TEQ} / \mathrm{g}$ & & \\
\hline Vegetation & Germany & 0.53-1.64 pg TEQ/g & & Pine needles \\
\hline Vegetation & Austria & $0.3-1.9 \mathrm{pg} \mathrm{TEQ} / \mathrm{g}$ & & Spruce needles \\
\hline Birds and animals & India & $19-24 \mathrm{pg} / \mathrm{g}$ fat & {$[168]$} & Eagle \\
\hline Birds and animals & India & $150-200 \mathrm{pg} / \mathrm{g}$ fat & {$[168]$} & Osprey \\
\hline Birds and animals & India & $9.2-270 \mathrm{pg} / \mathrm{g}$ fat & {$[168]$} & Spotted Owlet \\
\hline Birds and animals & India & $1,300-2,700 \mathrm{pg}$ dioxins/g fat & {$[168]$} & Spotted Owlet liver \\
\hline Birds and animals & India & $620-1,000 \mathrm{pg}$ furans/g fat & {$[168]$} & Spotted Owlet liver \\
\hline Fish & Great Lakes & $<1-63 \mathrm{pg} \mathrm{TEQ} / \mathrm{g}$ & [169] & \\
\hline Fish & Great Lakes & $<1-59 \mathrm{pg} \mathrm{TEQ} / \mathrm{g}$ & {$[170]$} & Dioxin TEQ \\
\hline Fish & Great Lakes & $<1-182 \mathrm{pg} \mathrm{TEQ} / \mathrm{g}$ & {$[170]$} & PCB TEQ \\
\hline Fish & Finnish coast & 165-329 pg TEQ/g lipid & {$[171]$} & Herring muscle \\
\hline Fish & Adriatic Sea & 0.23-329 pg TEQ/g lipid & {$[171]$} & Mackerel $>$ Red mullet $>$ Anchovy \\
\hline Fish & Japan Sea & $0.10-0.95 \mathrm{pg} \mathrm{TEQ} / \mathrm{g}$ & & Cod \\
\hline Marine mammals & Bird Island & 2 pg TEQ/g blubber & {$[172]$} & Fur seals \\
\hline Marine mammals & Canadian Arctic & $2-23 \mathrm{pg} \mathrm{TEQ} / \mathrm{g}$ ww & {$[173]$} & Polar bears \\
\hline Marine mammals & Japan Sea & $0.71-13 \mathrm{pg} T E Q / g$ ww & & Whale \\
\hline Marine mammals & Japan Sea & $17-360 \mathrm{pg} \mathrm{TEQ} / \mathrm{g}$ ww & & Whale fat \\
\hline Marine mammals & Australia & $0.1-2.6 \mathrm{ng} / \mathrm{g} \mathrm{ww}$ & & Bottlenose dolphin \\
\hline Food & Europe & $0.3-2.5 \mathrm{pg} \mathrm{TEQ} / \mathrm{g}$ fat & {$[174]$} & Milk and dairy products \\
\hline Food & North America & $0.3-0.9 \mathrm{pg} T E Q / \mathrm{g}$ fat & {$[174]$} & Milk and dairy products \\
\hline Food & South America & $0.01-2.8 \mathrm{pg} \mathrm{TEQ} / \mathrm{g}$ fat & {$[174]$} & Milk and dairy products \\
\hline Food & Asia & $0.3-1.8 \mathrm{pg} T E Q / \mathrm{g}$ fat & {$[174]$} & Milk and dairy products \\
\hline Human milk & The Netherlands & $17.09-21.29 \mathrm{pg} T E Q / \mathrm{g}$ fat & & \\
\hline Human milk & Ukraine & 8.38-10.16 pg TEQ/g fat & & \\
\hline Human milk & Norway & 7.16-7.43 pg TEQ/g fat & & \\
\hline Human milk & Czech Republic & $7.44-10.73 \mathrm{pg} T E Q / g$ fat & & \\
\hline Human milk & Bulgaria & $5.08-7.11 \mathrm{pg} \mathrm{TEQ} / \mathrm{g}$ fat & & \\
\hline
\end{tabular}


Table 5 (continued)

\begin{tabular}{lllll}
\hline Matrix & Region & Concentration Range & Reference & Remarks \\
\hline Blood/serum/plasma & Great Lakes & $27.5 \mathrm{ng} \mathrm{TEQ} / \mathrm{L}$ & {$[175]$} & Recreational fishers \\
Blood/serum/plasma & Israel & $26.6-32 \mathrm{ng} \mathrm{TEQ} / \mathrm{g}$ fat & {$[176]$} & \\
Blood/serum/plasma & A So, Vietnam & $16.6-45.9 \mathrm{pg} \mathrm{TEQ} / \mathrm{g}$ lipid & {$[177]$} & \\
Blood/serum/plasma & New Zealand & $12.8 \mathrm{pg} \mathrm{TEQ/g} \mathrm{serum} \mathrm{fat}$ & {$[143]$} & 1,834 samples \\
\hline
\end{tabular}

All citations are UNEP (2003) [160] or individual UNEP Regional Assessments unless otherwise noted. ND denotes "not detected"; $w w$ denotes "wet weight"

$\mathrm{PCDD} / \mathrm{F}$ accumulation rates in the early 1990 s ranged from $<0.03 \mathrm{ng} \mathrm{cm}^{-2} \mathrm{y}^{-1}$ for Lake Superior to $0.39 \mathrm{ng} \mathrm{cm}^{-2} \mathrm{y}^{-1}$ for Lake Ontario; these rates represent $30-70 \%$ of maximum accumulation in the 1960s to 1970s. In his review, Norstrom noted the lack of comprehensive congener-specific PCDD/F data for Great Lakes sediment cores [141].

Cohen et al. [149] modeled atmospheric transport and deposition of PCDD/Fs to the Great Lakes using a United States and Canadian air emissions inventory based on data from 5,700 point sources and 42,600 area sources (Fig. 2). They identified municipal waste incineration, iron sintering, medical waste incineration and burning of hazardous waste in cement kilns as the most significant sources based on 1996 emissions data. Source areas up to 2,000 km removed from the Great Lakes were significant contributors. Combustion sources continue to be the predominant contributor to global ambient air levels of PCDD/Fs [150]. Subsequent long-range transport of combustion emissions are thought to be primarily responsible for the global ubiquity of PCDD/Fs [144, 151]. Fiedler recently reviewed global inventories of PCDD/Fs using national air inventories from 23 countries to formulate a global air flux estimated range of 7,500-13,000 g TEQs per annum [152]. Brzuzy and Hites estimated total global deposition from the atmosphere to land at $12,500 \pm 1,300 \mathrm{~kg} \mathrm{y}^{-1}$ [151]. A study published in 2000 by Wagrowski and Hites using tree bark and soil samples estimated global deposition from the atmosphere to land at $2-15 \mathrm{t} \mathrm{y}^{-1}$ [153].

The recent report by Fiedler also showed sources of PCDDs/Fs in developed countries to be different from developing countries [152]. In developed countries, industrial activities are the primary source category, while open-burning activities are the dominant source category in developing countries. However, burn barrels and other household garbage burning methods are estimated to emerge as the greatest source of $\mathrm{PCDD} / \mathrm{F}$ emissions in North America subsequent to implementation of new industrial air emission standards [154]. Open-burning processes include forest fires, pre- and post-harvest burning in agriculture, burning in landfills, and backyard burning. High releases were also estimated from incineration of medical waste. Emissions from municipal solid waste incineration (MSWI) were estimated to account for $70 \%$ of the PCDD/F burden from industrial sources in the United Kingdom in 1995 [129]; other significant sources included emissions from metal industries and coal combustion.
Industrial emissions account for roughly $90 \%$ of the total inventory in the United Kingdom [155]. Other combustion sources contributing to $\mathrm{PCDD} / \mathrm{F}$ emissions in industrialized countries include metal reclamation, wood burning, chemical fires, automobile exhaust, cement kilns and cigarette smoke. Non-combustion sources include chemical production (pesticides, perchloroethylene, pentachlorophenol), metal production, and pulp and paper mills. Recent data on PCDD/F emissions for individual industrialized countries has been reported for the Netherlands [156], the United Kingdom [157], the United States [130] and Canada [158]. A global PCDD/F emission inventory was reported by the United Nations Environmental Program [159]. The multimedia occurrence of PCDD/Fs globally in industrialized countries is fairly well documented; however, data are generally far less common than for other chemicals such as PCBs and organochlorine pesticides. UNEP [160] has produced a report on global trends in persistent toxics, including $\mathrm{PCDD} / \mathrm{Fs}$. Table 5 shows selected global data for levels of PCDD/Fs in a variety of matrices, based on information cited in the UNEP report.

Profiles of PCDD/Fs in abiotic matrices including air, soils, and sediments in some areas can reflect the source emission profile. However, a confounding factor in attributing PCDD/F contamination to specific sources can be a contrast in profiles between source samples and corresponding profiles in environmental sinks, e.g., soils and sediments, due to degradation, weathering, or transformation processes [161]. Eitzer and Hites observed a "consistent and systematic change" from a combustion source profile to a sediment profile as a result of long-range transport and depositional processes [162]. Tysklind et al. attributed differences in PCDD/F source profiles and air profiles to transformation processes including photolytic degradation or hydroxyl radical reactions [163]. Koester and Hites reported that wet and dry deposition are important mechanisms for scrubbing PCDD/Fs from the atmosphere, and that these mechanisms contribute to the predominance of OCDD in sediments [164]. Ultimately, the PCDD/F profile in environmental samples can be influenced by both source type and environmental processes.

Studies of congener and homolog profiles for source apportionment have been carried out in abiotic matrices; biota have a tendency to accumulate primarily the $2,3,7,8$ substituted compounds due to non-2,3,7,8-substituted 
congeners being metabolized $[129,161]$. There are numerous examples of studies of the variation of PCDD/F congener and homolog profiles with source (e.g., [161, 144-147]); these studies have also illustrated how different sources of $\mathrm{PCDD} / \mathrm{Fs}$ have influenced temporal trends, primarily according to production, use and disposal of chlorinated organics. Principal component analysis (PCA) of profiles of source and sink samples have also proven to be a valuable tool for source apportionment $[146,147,161$, 163].

\section{References}

1. Clement RE, Koester CJ, Grey L (1994) In: Kiceniuk JW, Ray $\mathrm{S}$ (eds) Analysis of contaminants in edible aquatic resources. VCH, New York, Ch 4, pp 347-377

2. Clement RE (1991) Anal Chem 63:1130A-1139A

3. Clement RE, Tosine HM (1989) In: Afghan BK, Chau ASY (eds) Analysis of trace organics in the aquatic environment. CRC, Boca Raton, FL, Ch 5, pp 151-204

4. Clement RE, Tosine HM (1988) Mass Spec Rev 7:593-636

5. Ryan JJ, Conacher HBS, Panapio LG, Lau BPY, Hardy JA, Masuda Y (1991) J Chromatogr 541:131-183

6. Clement RE, Tosine H, Osborne J, Ozvacic V, Wong G (1988) Biomed Environ Mass Spec 17:81-96

7. Crummett WB, Stehl RH (1973) Environ Health Perspect 5:15

8. Poland A, Knutson JC (1982) Annu Rev Pharmacol Toxicol 22:517-554

9. Pohjanvirta R, Tuomisto J (1994) Pharmacol Rev 6:483-549

10. Okey AB, Riddick DS, Harper PA (1994) Toxicol Lett 70:1-22

11. Birnbaum LS, Tuomisto J (2000) Food Addit Contam 17:275-288

12. Yu ML, Guo YL, Hsu CC, Rogan WJ (2000) Int J Epidemiol 29:672-677

13. Rogan WJ, Gladen BC, Hung KL, Koong SL, Shih LY, Taylor JS, Wu YC, Yang D, Ragan NB, Hsu CC (1988) Science 241:334-336

14. Alaluusua S, Calderara P, Gerthoux PM, Lukinmaa PL, Kovero O, Needham L, Patterson DG Jr, Tuomisto J, Mocarelli P (2004) Environ Health Perspect 112:1313-1318

15. Kern PA, Said S, Jackson WG Jr, Michalek JE (2004) J Clin Endocrinol Metab 89:4665-4672

16. Steenland K, Bertazzi P, Baccarelli A, Kogevinas M (2004) Environ Health Perspect 112:1265-1268

17. De Roos AJ, Hartge P, Lubin JH, Colt JS, Davis S, Cerhan JR, Severson RK, Cozen W, Patterson DG Jr, Needham LL, Rothman N (2005) Cancer Res 65:11214-11226

18. Hays SM, Aylward LL (2003) Regul Toxicol Pharmacol 37:202-217

19. Starr TB (2003) Environ Health Perspect 111:1443-1447

20. Geusau A, Abraham K, Geissler K, Sator MO, Stingl G, Tschachler E (2001) Environ Health Perspect 109:865-869

21. Bunger MK, Moran SM, Glover E, Thomae TL, Lahvis GP, Lin BC, Bradfield CA (2003) J Biol Chem 278:17767-17774

22. Walisser JA, Bunger MK, Glover E, Harstad EB, Bradfield CA (2004) J Biol Chem 279:16326-16331

23. Okey AB, Franc MA, Moffat ID, Tijet N, Boutros PC, Korkalainen M, Tuomisto J, Pohjanvirta R (2005) Toxicol Appl Pharmacol 207:S43-S51

24. Gu YZ, Hogenesch JB, Bradfield CA (2000) Annu Rev Pharmacol Toxicol 40:519-561

25. Tijet N, Boutros PC, Moffat ID, Okey AB, Tuomisto J, Pohjanvirta R (2006) Mol Pharmacol 69:140-153

26. Safe S (1990) Crit Rev Toxicol 21:51-88

27. Haws LC, Su SH, Harris M, Devito MJ, Walker NJ, Farland WH, Finley B, Birnbaum LS (2006) Toxicol Sci 89:4-30
28. Safe S (1997) Teratog Carcinog Mutagen 17:285-304

29. Safe SH (1998) J Anim Sci 76:134-141

30. Tuomisto J (2005) Toxicol Appl Pharmacol 207:2-10

31. Viluksela M, Stahl BU, Birnbaum LS, Rozman KK (1998) Toxicol Appl Pharmacol 151:70-78

32. Walker NJ, Crockett PW, Nyska A, Brix AE, Jokinen MP, Sells DM, Hailey JR, Easterling M, Haseman JK, Yin M, Wyde ME, Bucher JR, Portier CJ (2005) Environ Health Perspect 113:43-48

33. Van Birgelen AP, Van der Kolk J, Fase KM, Bol I, Poiger H, Brouwer A, Van den Berg M (1994) Toxicol Appl Pharmacol 127:209-221

34. Haag-Gronlund M, Johansson N, Fransson-Steen R, Hakansson H, Scheu G, Warngard L (1998) Toxicol Appl Pharmacol 152:153-165

35. Toyoshiba H, Walker NJ, Bailer AJ, Portier CJ (2004) Toxicol Appl Pharmacol 194:156-168

36. Windal I, Denison MS, Birnbaum LS, Van Wouwe N, Baeyens W, Goeyens L (2005) Environ Sci Technol 39:7357-7364

37. Van den Berg M, Birnbaum L, Bosveld AT, Brunstrom B, Cook P, Feeley M, Giesy JP, Hanverg A, Hasegawa R, Kennedy SW, Kubiak T, Larsen JC, van Leeuwen FX, Liem AK, Nolt C, Peterson RE, Poellinger L, Safe S, Schrenk D, Tillit D, Tysklind M, Younes M, Waern F, Zacharewski T (1998) Environ Health Perspect 106:775-792

38. US EPA (1994) Method 1613, Revision B: Tetra- through octachlorinated dioxins and furans by isotope dilution HRGC/ HRMS, EPA 821-B94-0059. Office of Water, US Environmental Protection Agency, Washington, DC

39. US EPA (1999) Method 1668, Revision A: Chlorinated biphenyl congeners in water, soil, sediment, and tissue by HRGC/HRMS, EPA-821-R-00-002. Office of Water, US Environmental Protection Agency, Washington, DC

40. Taylor KZ, Waddell DS, Reiner EJ, MacPherson KA (1995) Anal Chem 67:1186-1190

41. Pujadas E, Diaz-Ferrero J, Marti R, Broto-puig F, Comellas L, Rodriguez-Larena MC (2001) Chemosphere 43:449-454

42. Focant JF, Pirard C, DePauw E (2004) Talanta 63:1101-1113

43. Dionex (1999) Dionex Application Note 323: Extraction of polychlorinated dibenzo-p-dioxins and polychlorinated dibenzofurans from environmental samples using accelerated solvent extraction (ASE). Dionex, Sunnyvale, CA

44. Richter BE, Jones BA, Ezzell JL, Porter NL, Avdalovic N, Pohl C (1996) Anal Chem 68:1033-1039

45. US EPA (1995) Method 23: Determination of polychlorinated dibenzo-p-dioxins and polychlorinated dibenzofurans from municipal waste combustors. US Environmental Protection Agency, Washington, DC

46. US EPA (1994) SW-846 Method 8290: Polychlorinated dibenzodioxins and polychlorinated dibenzofurans by highresolution gas chromatography/high-resolution mass spectrometry, Revision 0. US Environmental Protection Agency, Washington, DC

47. ISO (2004) ISO 18073: Water quality-Determination of tetrato octa-chlorinated dioxins and furans-Method using isotope dilution HRGC/HRMS. International Organization for Standardization (ISO), Geneva, Switzerland

48. ISO (2006) ISO 17585: Water quality-Determination of dioxin-like polychlorinatedbiphenyls-Method using gas chromatography and mass spectrometry. International Organization for Standardization (ISO), Geneva, Switzerland (in press)

49. CEN (1997) European Standard EN 1948: Stationary source emissions, determination of the mass concentration of PCDDs/ PCDFs. CEN, Brussels, Belgium

50. Ontario Ministry of the Environment (2004) The determination of polychlorinated dibenzo- $p$-dioxins, polychlorinated furans and dioxin-like PCBs in environmental matrices by $\mathrm{GC}$ HRMS. Environment Ontario Laboratory Services Branch Method DFPCB-E3418. Ontario Ministry of the Environment, Toronto, ON, Canada 
51. Environment Canada (1992) Reference method for the determination of PCDDs and PCDFs in pulp and paper mill effluents, Report EPS 1/RM/19. Environment Canada, Burlington, ON, Canada

52. JSA (1999) JIS K0311: Method for determination of tetrathrough octa-chlorodibenzo- $p$-doxins, tetra- through octachlorinated furans and coplanar polychlorinated biphenyls in stationary source emissions. Japanese Standards Association, Tokyo, Japan

53. JSA (1999) JIS K0312: Method for determination of tetrathrough octa-chlorodibenzo- $p$-doxins, tetra- through octa-chlorinated furans and coplanar polychlorinated biphenyls in industrial water and wastewater. Japanese Standards Association, Tokyo, Japan

54. Ahmed F (2003) Trends Anal Chem 22:170-185

55. Rawa-Adkonis M, Wolska L, Namiesnik J (2003) Crit Rev Anal Chem 33(3):199-248

56. Sun Y, Takaoka M, Takeda N, Matsumoto T, Oshita K (2005) J Sep Sci 28:585-588

57. Namiesnik J, Zabigala B, Kot-Wasik A, Partyaka M, Wasik A (2005) Anal Bioanal Chem 381:279-301

58. Mannila M, Koistinen J, Vartiainen T (2002) J Chromatogr A 975:189-198

59. VanBeuzekom AC, Hijman WC, Berkhoff CJ, Stoffelsen BHG, DenBoer AC, Groenemeijer GS, Mooibroek D, Hoogerbrugge R, Broekman MH, Baumann RA, Hogendoorn EA (2004) Talanta 63:1183-1191

60. Vrana B, Mills GA, Allan IJ, Domiiak E, Svensson K, Knutsson J, Morrison G, Greenwood R (2005) Trends Anal Chem 24:845-868

61. Petty JD, Orazio CE, Huckins JN, Gale RW, Lebo JA, Meadows JC, Echols KR, Cranor WL (2000) J Chromatogr A 879:83-95

62. Rayne S, Ikonomou MG, Butt CM, Diamond ML, Troung J (2005) Envrion Sci Technol 39:1995-2003

63. Lucaciu CM, Fayez L, Reiner EJ, Kolic TM, Boden AR, MacPherson KA, Crozier PW, Wania F, Emerson R (2004) Organohalog Compd 66:153-156

64. Hanari N, Horii Y, Okazawa T, Falandysz J, Bochentin I, Orlikowska A, Puzyn T, Wyrzykowska B, Yamashita N (2004) J Environ Monit 6:305-312

65. Lamparski LL, Nesterick TJ, Stehl RH (1979) Anal Chem $51: 1453-1458$

66. Smith LM, Stallings DL, Johnson JL (1984) Anal Chem $56: 1830-1842$

67. Chang RR, Jarman WM, King CC, Esperanza CC, Stephens RD (1990) Chemosphere 20:881-886

68. Focant JF, DePauw E (2002) J Chromatogr B 776:199-212

69. L Fayez, R Brunato, Reiner E (2005) Organohalog Compd 67:565-568

70. Thal D, Kelly HP (2005) Organohalog Compd 67:157-158

71. Norstrom RJ, Simon M, Mulvihill MJ (1986) Int J Environ Anal Chem 23:267-287

72. Nording M, Sporring S, Wiberg K, Borklund E, Haglund P (2005) Anal Bioanal Chem 381:1472-1475

73. Reiner E, Boden A, MacPherson K, Koic T, Dorman F, Cochran J (2004) Organohalog Compd 66:838-845

74. Dorman F, Reese S, Reiner E, MacPherson K, Focant J, Cochran J (2004) Organohalog Compd 66:834-837

75. DiFeo D Jr (2004) LC GC N Am 18:38

76. Naikwadi N, Britten A, Reiner EJ (2005) Organohalog Compd 67:404-407

77. Chang-Chien GP, Lee WS, Tsai JL, Jeng SH (2001) J Chromatogr A, 932:97-105

78. MacPherson KA, Reiner EJ, Chen T, Brunato R, Bogard MA (1999) Organohalog Compd 40:19-23

79. Reiner EJ, MacPherson KA, Brunato R, Chen T, Bogard MA, Boden AR, Ladwig G (2000) Organohalog Compd 45:17-20

80. Korytar P, Janssen HG, Matisova E, Brinkman UATh (2002) Trends Anal Chem 21:558-572

81. MacPherson KA, Reiner EJ, Kolic TM (2001) Organohalog Compd 50:40-43
82. Focant JF, Reiner EJ, MacPherson K, Kolic T, Sjodin A Patterson Jr DG, Reese SL, Dorman FL, Cochran J (2004) Talanta 63:1231-1240

83. VanLoco J, VanLeeuwen SPJ, Roos P, Carbonnelle S, deBoer J, Goeyens L, Beernaert H (2004) Talanta 63:1169-1182

84. Marriott PJ, Haglund P, Ong RCY (2003) Clin Chim Acta 328:1-19

85. Kemmochi Y, Tsutsumi K, Nakazawa H (2003) J Chromatogr A 1016:249-256

86. Focant JF, Sjodin A, Patterson DG Jr (2004) J Chromatogr A 1040:227-238

87. Danielsson C, Wiberg K, Korytar P, Bergek S, Brinkman UATh, Haglund P (2005) J Chromatogr A 1086:61-70

88. Korytar P, Danielsson C, Leonards PEG, Haglund P, DeBoer J, Brinkman UATh (2004) J Chromatogr A 1038:189-199

89. Focant JF, Eppe G, Scipo ML, Massart AC, Piard C, MaghuinRogister G, DePauw E (2005) J Chromatogr A 1086:46-60

90. Korytar AP, Parera J, Leonards PEG, DeBoer J, Brinkman UATh (2005) J Chromatogr A 1067:225-264

91. Petrovic M, Eljarrat E, Lopezde Alda MJ, Barcelo D (2002) J Chromatogr A 974:23-51

92. Focant JF, Pirard C, Eppe G, DePauw E (2005) J Chromatogr A 1067:265-275

93. McCurvin DMA, Clement RE, Taguchi VY, Reiner EJ, Schellenberg DH, Bobbie BA (1989) Chemosphere 19:205-212

94. Rushneck DR, Beliveau A, Fowler B, Hamilton C, Hoover D, Kaye K, Berg M, Smith T, Telliard WA, Roman H, Ruder E, Ryan L (2004) Chemosphere 54:79-87

95. Rushneck DR, Beliveau A, Fowler B, Hamilton C, Hoover D, Kaye K, Berg M, Smith T, Telliard WA, Roman H, Ruder E, Ryan L (2005) Chemosphere 58:1151

96. Eppe G, Cofino WP, DePauw E (2004) Anal Chim Acta 519:231-242

97. Eppe G, Maghuin-Rogister G, DePauw E (2004) Anal Chim Acta 519:243-253

98. Charles MJ, Green B, Tondeur JR, Hass R (1989) Chemosphere 19:51-57

99. Reiner EJ, Schellenberg DH, Taguchi VY (1991) Environ Sci Technol 25:110-117

100. Reiner EJ, Schellenberg DH Taguchi VY, Mercer RS, Townsend JA, Thompson TS, Clement RE (1990) Chemosphere 20:1385-1392

101. March RE, Splendore M, Reiner EJ, Mercer RS, Plombley JB, Waddell DS, MacPherson KA (2000) Int J Mass Spectrom 197:283-297

102. Eppe G, Focant JF, Pirard C, DePauw E (2004) Talanta 63:1135-1146

103. Harrison AG (1992) Chemical ionization mass spectrometry. CRC, Boca Raton, FL

104. Chernestsova ES, Revelsky AI, Revelsky IA, Mikhasenko IA, Sobolevsky TG (2002) Mass Spectrom Rev 21:373-387

105. Koester CJ, Harless RL, Hites RA (1992) Chemosphere 24:421-426

106. Sherry J (1997) Chemosphere 34:1011-1025

107. Shan G, Leeman WR, Gee SJ, Sanborn JR, Jones AD, Chang DPY, Hammock BD (2001) Anal Chim Acta 444:169-178

108. Nichkova M, Park EK, Koivunen ME, Kamita SG, Gee SJ, Chuang J, VanEmon JM, Hammock BD (2004) Talanta 63:1213-1223

109. Harrison RO, Eduljee GH (1999) The Science of the Total Environment 239:1-18

110. US EPA (2002) Method 4025: Screening for polychlorinated dibenzodioxins and polychlorinated dibenzofurans (PCDD/Fs) by immunoassay. US Environmental Protection Agency, Washington, DC

111. Takigami H, Dakai S, Brouwer A (2005) Environ Technol 26:459-469

112. VanOvermeire I, VanLoco J, Roos P, Carbonnelle S, Goeyens L (2004) Talanta 63:1241-1247

113. Scippo ML, Eppe G, DePauw E, Maghuin-Rogister G (2004) Talanta 63:1193-1202 
114. Windal I, VanWouwe N, Eppe G, Xhrouet C, Debacker V, Baeyens W, DePauw E, Goeyens L (2005) Environ Sci Technol 39:1741-1748

115. Van Wouwe N, Windal I, Vanderperren H, Eppe G, Xhrouet C, Massart AC, Debacker N, Sasse A, Baeyens W, De Pauw E, Sartor F, VanOyen H, Goeyens L (2004) Talanta 63:1157-1167

116. Besselink HT, Schipper C, Klamer H, Leonards P, Verhaar H, Felzel E, Murk AJ, Thain J, Hosoe K, Schoeters G, Legler J, Brouwer B (2004) Environ Toxicol Chem 23:2781-2789

117. VanWouwe N, Windal I, Vanderperren H, Eppe G, Xhrouet C, DePauw E, Goeyens L, Baeyens W (2004) Talanta 63:1269-1272

118. Warner M, Eskenazi B, Patterson DG Jr, Clark G, Turner WE, Bonsignore L, Mocarelli P, Gerthoux PM (2005) J Expo Anal Environ Epidemiol 15:310-318

119. Pirard C, DePauw E, Focant JF (2003) J Chromatogr A 998:169-181

120. Barcelo EE (2003) Trends Anal Chem 22:655-665

121. Koh Ch, Khim JS, Villeneuve DL, Kannan K, Johnson BG, Giesy JP (2005) Ecotoxicol Environ Saf 61:366-379

122. Liu H, Zhang Q, Cai Z, Li A, Wang Y, Jian G (2006) Anal Chim Acta 557:314-320

123. Selliah SS, Cussion S, MacPherson KA, Reiner EJ, Toner D (2001) Fresenius J Anal Chem 370:208-212

124. Frazer CA, Gardner GJ, Maxwell PS, Kubwabo C, Guevremont R, Siu KWM, Berman SS (1995) Fresenius J Annal Chem 352:143-147

125. Poster DL, Kucklick JR, Schantz MM, Porter BJ, Leigh SD, Wise SA (2003) Anal Bioanal Chem 375:233-241

126. EUROCHEM/CITAC (2000) Guide for quantifying uncertainty in analytical measurement, 2nd edn. EUROCHEM/ CITAC, Budapest, Hungary

127. Steinke G, Brunato R, Fracassi J, MacPherson K, Ontario Ministry of the Environment (2002) The estimation of uncertainty for Method E3418-UNC-E3418. Ontario Ministry of the Environment, Toronto, ON, Canada

128. Baccarelli A, Pfeiffer R, Consonni D, Pesatori AC, Bonzini M, Patterson DG, Bertazzi PA, Landi MT (2005) Chemosphere 60:898-906

129. Alcock AE, Jones KC (1996) Environ Sci Technol 30:3133-3143

130. US EPA (2005) The inventory of sources of dioxin in the United States (external draft review 2005). EPA/600/p03/002a. US Environmental Protection Agency, Washington, DC

131. Päpke O (1998) Environ Health Perspect 106:723-731

132. Gaus C, Brunskill GJ, Weber R, Papke O, Muller JF (2001) Environ Sci Technol 35:4597-4603

133. Kjeller L-O, Jones KC, Johnston AE, Rappe C (1991) Environ Sci Technol 25:1619-1627

134. Hoekstra EJ, de Weerd H, de Leer EWB, Brinkman UATh (1999) Environ Sci Techol 33:2543-2549

135. Alcock RE, McLachlan MS, Johnston AE, Jones KC (1998) Environ Sci Technol 32:1580-1587

136. Green N, Jones JL, Johnston AE, Jones KC (2001) Environ Sci Technol 35:1974-1981

137. Juttner I, Henkelmann, B, Schramm K-W, Steinberg CEW, Winkler R, Kettrup A (1997) Environ Sci Technol 31:806-812

138. Hashimoto S, Wakimoto T, Tatsukawa R (1990) Chemosphere $21: 825-835$

139. Hicks J, McColl S (1995) Exposure assessment of airborne dioxins and furans emitted from the EDC/VCM facility at the Dow Chemical Canada Fort Saskatchewan site. Institute for Risk Research, University of Waterloo, Waterloo, Ontario, Canada

140. Rappe C, Andersson R, Bergqvist P-A, Hannson M, Kjeller L-O, Lindstrom G, Marklund S, Nygren M, Swanson S, Tyslind M, Wiberg K (1987) Waste Manage Res 5:225-237
141. Norstrom RJ (2006) Polychlorinated dibenzo- $p$-dioxins and dibenzofurans in the Great Lakes. In: Hites R (ed) Persistent organic pollutants in the Great Lakes. Springer, Berlin Heidelberg New York, Ch 3, pp 71-150

142. Howdeshell MJ, Hites RA (1996) Environ Sci Technol 30:969-974

143. Buckland S, Ellis H, Salter R (1998) Organochlorines in New Zealand: Ambient concentrations of selected organochlorines in soils. Organochlorines Programme, Ministry for the Environment, Wellington, New Zealand

144. Czuczwa JM, Hites RA (1984) Environ Sci Technol 18:444-450

145. Kjeller L-O, Rappe C (1995) Environ Sci Technol 29:346-355

146. Czuczwa JM, Hites RA (1986) Environ Sci Technol 20:195-200

147. Czuczwa JM, Hites RA (1986) Chemosphere 15:1417-1420

148. Pearson RF, Swackhamer DL, Eisenreich SJ, Long DT (1997) Environ Sci Technol 31:2903-2909

149. Cohen MD, Draxler RR, Artz R, Commoner B, Bartlett P, Cooney P, Couchot K, Dickar A, Eisl H, Hill C, Quigley J, Rosenthal JE, Niemi D, Ratte D, Deslauriers M, Laurin R, Mathewson-Brake L, McDonald J (2002) Environ Sci Technol $36: 4831-4845$

150. Fiedler H (1996) Chemosphere 32:55-64

151. Brzuzy LP, Hites RA (1996) Environ Sci Technol 30: $1797-1804$

152. Fiedler H (2005) In: Alaee M, Reiner E, Clement R (eds) Commemorating 25 years of Dioxin Symposia. Commemorative book distributed to delegates of the 25th Int Dioxin Conf, 21-26 Aug 2005, Toronto, Canada, Ch 6, pp 15-19

153. Wagrowski D, Hites R (2000) Environ Sci Technol 34 2952-2958

154. Great Lakes Binational Toxics Strategy (2002) Report of the Dioxins/Furans Workgroup. US EPA, Washington, DC

155. Duarte-Davidson R, Sewart A, Alcock RE, Cousins IT, Jones KC (1997) Environ Sci Technol 31:1-11

156. TNO (1993) Report 770501003. Netherlands Organization for Applied Scientific Research (TNO), VK Delft, The Netherlands

157. Douben PET (1997) Chemosphere 34:1181-1189

158. Environment Canada (2004) The National Pollutant Release Inventory webpage. Environment Canada, Burlington, ON, Canada (see http://www.ec.gc.ca/pdb/npri/npri_home_e.cfm, last accessed 8th May 2006)

159. United Nations Environmental Program (1999) Dioxin and furan inventories: National and regional emissions of PCDD/ PCDF. UNEP Chemicals, Chátelaine, Switzerland

160. United Nations Environmental Program (2003) 2003 Global report: Regionally based assessment of persistent toxic substances. UNEP Chemicals, Chátelaine, Switzerland

161. Rappe C (1994) Fresenius J Anal Chem 348:63-75

162. Eitzer BD, Hites RA (1989) Environ Sci Technol 23: $1396-1401$

163. Tysklind M, Fängmark I, Marklund S, Lindskog A, Thaning L, Rappe C (1993) Environ Sci Technol 27:2190-2197

164. Koester CJ, Hites RA (1992) Environ Sci Technol 26: $1375-1382$

165. Marvin $\mathrm{CH}$, Stern G, Reiner E, MacPherson K, Kolic T, Braekevelt E, Painter S (2002) J Great Lakes Res 29:317-331

166. Fattore E, Benfenati G, Mariani G, Fanelli R, Evers EHG (1997) Environ Sci Technol 31:1777-1784

167. Eljarrat E, Caixach J, Rivera J (2001) Chemosphere 44: $1383-1387$

168. Kumar KS, Kannan K, Paramasiban ON, Sundaram SO, Nakanishi L, Masunaga S (2001) Environ Sci Technol $35: 3448-3455$

169. Reiner EJ, MacPherson KA, Kolic TM, Hayton A, Clement RE (1995) Organohalog Compd 24:379-382

170. Kolic TM, MacPherson KA, Reiner EJ, Gobran T, Hayton A (2000) Organohalog Compd 46:562-565 
171. Bayarri S, Baldassarri LT, Iacovella N, Ferrara F, di Domenico A (2001) Chemosphere 43:601-610

172. Oehme M, Schlabach M, Boyd IL (1995) Ambio 24:41-46

173. Norstrom RJ, Simon M, Muir DCG (1990) Environ Pollut 66:1-19

174. FAO/WHO (2003) Joint FAO/WHO food standards programme codex committee on food additives and contaminants. Position paper on dioxins and dioxin-like PCBs, CX/ FAC03/32. FAO/WHO, Rome, Italy, pp 32
175. Andersson T, Forlin T, Herdig J, Larson A (1998) Can J Fish Aquat Sci 45:1525-1546

176. Schecter A, Päpke O, Fürst P, Ryan JJ (1997) Organohalog Compd 33:457-461

177. Dwernychuk LW, Hoang DC, Hatfield CT, Boivin TG, Tran MH, Phung TD, Nguyen DT (2002) Chemosphere 47:117-137

178. Patterson DG, Wellech SM, Turner W, Focant JF (2005) Organohalog Compd 67:107-109 